\title{
"WHALE ISLAND" AND THE MACKENZIE DELTA: CHARTED ERRORS AND UNMAPPED DISCOVERIES, 1789 to 1850
}

\author{
T. F. Bredin
}

$\mathbf{I}^{\mathrm{N}}$ 1825 Sir John Franklin began his second expedition to the shores of the Arctic Ocean. In August of that year he travelled down the Mackenzie River to its mouth; his purpose was to have a quick look at the lie of the land before setting out on a westward coastal exploration in the following summer.

Travelling in the footsteps of its discoverer, Franklin followed the river to the open sea, where he named the site of his northernmost camp Garry Island. This "is about five miles long, by two broad, and seems to be a mass of frozen mud" (Franklin 1825a, p. 235-6; 1828, p. 37). The position of Franklin's camp was $69^{\circ} 28^{\prime} 52^{\prime \prime}$ N. $135^{\circ} 40^{\prime} 55^{\prime \prime} \mathrm{W}$.

Mackenzie in 1789 ended his journey at "Whale Island", which he described as being "about seven leagues in length, East and West by compass; but not more than half a mile in breadth" (Mackenzie 1801, p. 65). At the westernmost point of the island he calculated his latitude as $69^{\circ} 14^{\prime} \mathrm{N}$. At the eastern end of the island he later obtained $69^{\circ} 07^{\prime} \mathrm{N}$.

Mackenzie's map of his track to the Arctic shows "Whale Island" (Mackenzie 1801), (Fig. 1). No-one, including Franklin, seems to have looked very closely at it, for the island as drawn there has not appeared on any other map of the Mackenzie Delta. Franklin also mapped "Whale Island" (Franklin 1828). He plotted it as 20 miles long, running northwest and southeast roughly between $69^{\circ} 14^{\prime} \mathrm{N}$. and $69^{\circ} 07^{\prime} \mathrm{N}$, which were Mackenzie's recorded latitudes. Beside the island is the qualifying phrase: "According to Sir Alexander Mackenzie" (Fig. 2). Franklin's mapping of the island is unquestionably based on Mackenzie's description.

Later chartmakers copied Franklin's map but omitted the qualifying phrase. In fact "Whale Island", as Franklin had mapped it, appeared without change on Admiralty charts until a few years ago. The Bering Sea and Strait Pilot still says: "Whale Island lies with its north western extreme about twelve miles S. E. of Garry Island". 
The first accurate mapping of the Mackenzie Delta came as a result of aerial photography carried out between 1939 and 1945. "Whale Island", as described by Mackenzie and mapped by Franklin, cannot be found on any large-scale Canadian maps based on these aerial photographs. When the fact was drawn to its attention, the former Canadian Board on Geographical Names rescinded the name "Whale Island" (see Arctic 13:143, 1960).

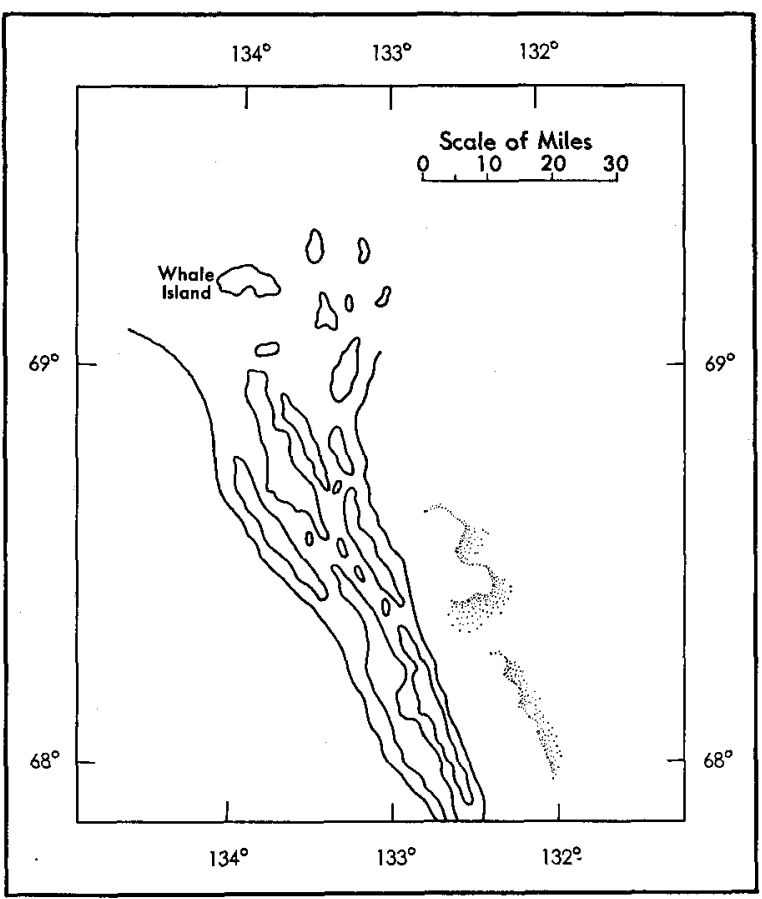

Fig. 1. Redrawn and enlarged detail of "A Map of Mackenzie's Track from Fort Chipewyan to the North Sea in 1789".

Perhaps "Whale Island" can be identified by reconstructing parts of Mackenzie's voyage to the Arctic. When his route is plotted on a modern map, it becomes evident that some of his distances and directions are incorrectly reported and some even left out. However, by noting his descriptions of natural features, certain stopping points can be located with absolute certainty and most with a fair degree of accuracy. Two interesting and demonstrable errors reveal themselves.

First, the co-ordinates of Mackenzie's six noon stops at Great Slave Lake, which he made to check his latitude, can be determined. In each instance the recorded latitude is south of the actual position. The range of this recurring error is about 6 to 16 minutes. After leaving the lake Mackenzie made only four more observations and they also can be proved to be south of his actual positions.

Second, Mackenzie's recorded compass directions of travel are always more westerly than his true directions, as one would expect; but the range of differences is wide and often greater than the magnetic variation. It is 


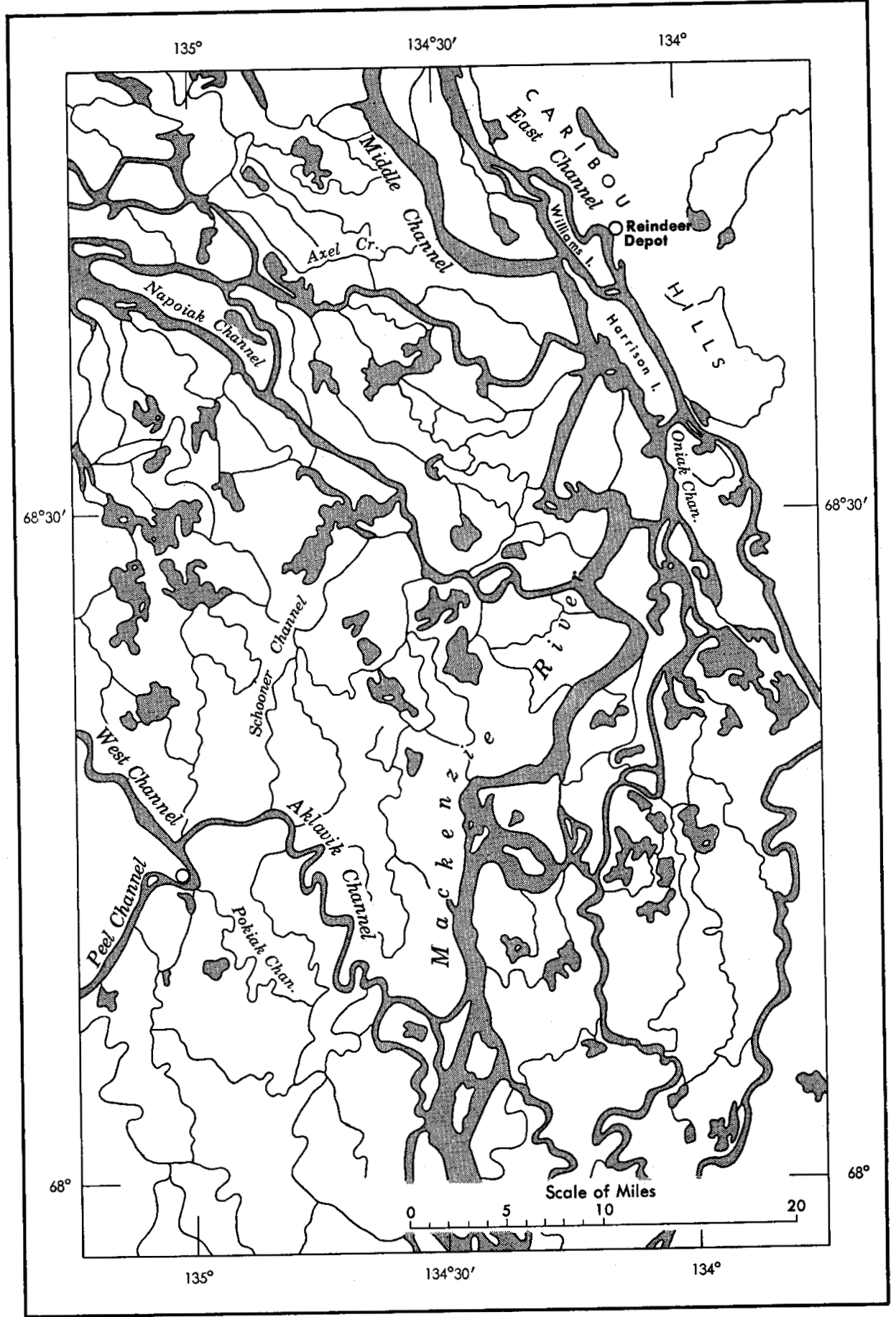

Fig. 4. Redrawn detail of National Topographic Series Sheet Port Brabant, 107 S.W. and 107 S.E. 1:506,880 (actual size). 
not uncommon to find compass directions 30 or 40 , and occasionally 50 degrees less easterly than the true direction of long and relatively straight stretches of the Mackenzie River. About 45 degrees must be added to convert a compass to a true direction.

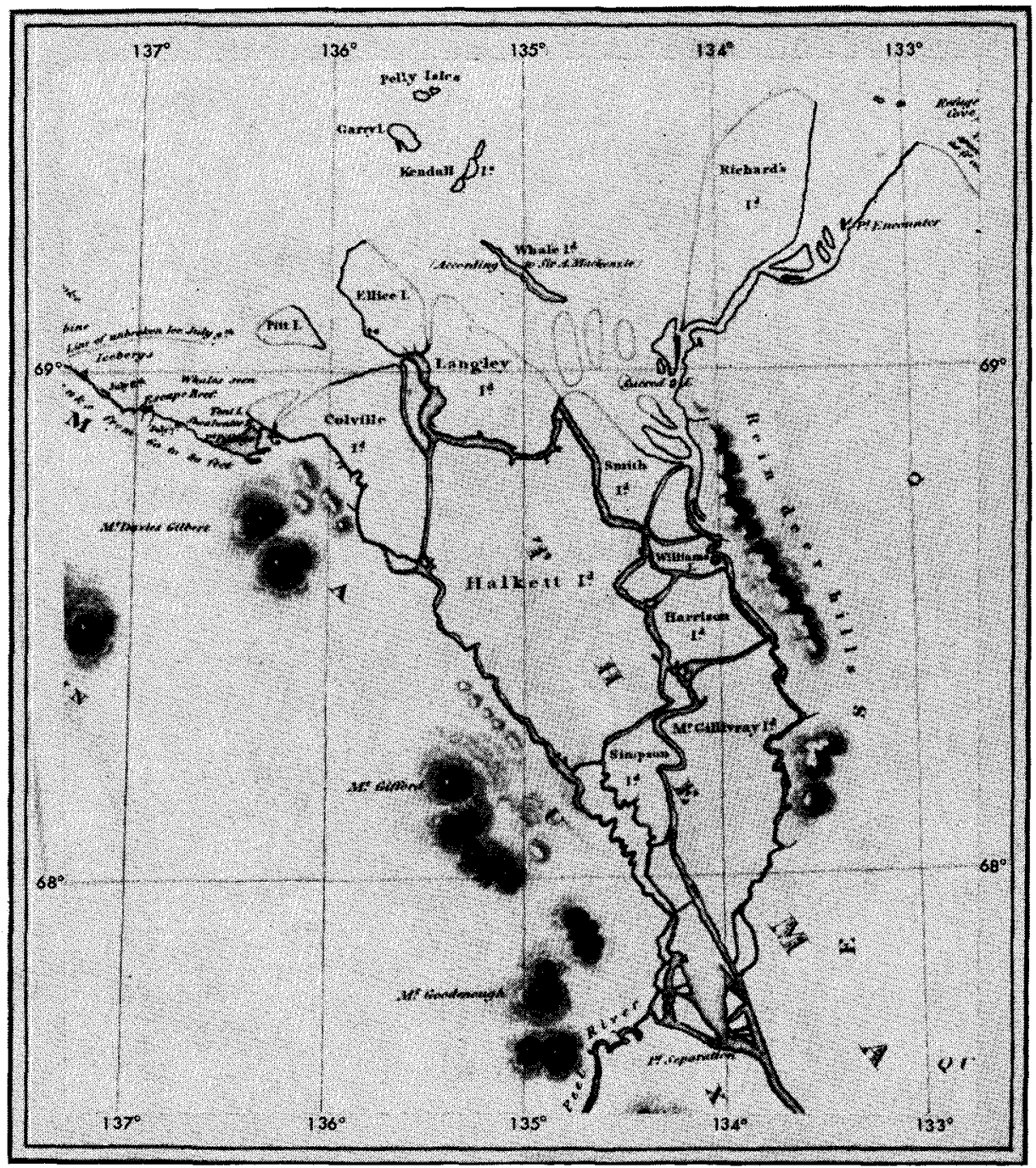

Fig. 2. Detail of map in Franklin 1828 (slightly reduced).

On July 10 Mackenzie set out from a camp near Arctic Red River, well within the Arctic Circle. Soon after embarking at 4 a.m. the canoes passed through the Lower Ramparts and shortly after came to Point Separation and the beginning of the Mackenzie Delta. "Here the river widens, and 


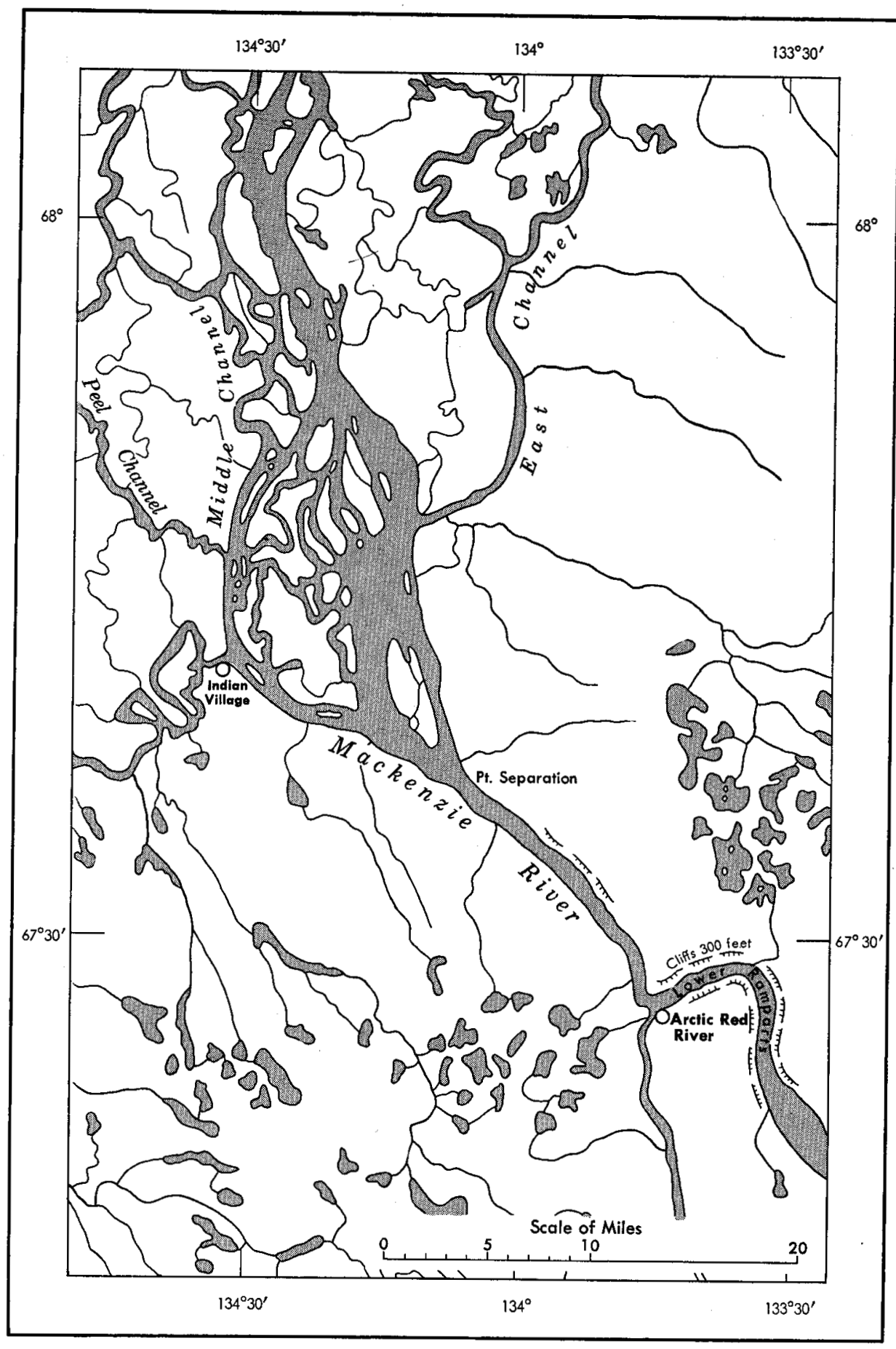

Fig. 3. Redrawn detail of National Topographic Series Sheet Arctic Red River, 106 N.W. and 106 N.E. 1:506,880 (actual size). 
runs through various channels. ... I determined to take the middle channel ... a larger body of water and running North and South." (Mackenzie 1801, p. 53.) He is following the Middle Channel marked on present-day maps (Fig. 3).

"I obtained an observation this day that gave me 67.47 North latitude" (p. 54). If the amount of Mackenzie's latitude-finding error is added to this, then he travelled about 50 miles before noon. His speed was about 6 miles an hour. After noting the sun's noon elevation, Mackenzie headed in one direction for 32 miles and then twisted through a series of snaking courses of $4,3,2,3$, and 2 miles before pitching camp at "eight in the evening" ( $p$. $55)$. He covered the total of 46 miles in less than 8 hours, and his speed was again about 6 miles an hour.

A study of Mackenzie's narrative and of a large-scale map shows that he camped somewhere near latitude $68^{\circ} 20^{\prime} \mathrm{N}$. on the Middle Channel. This estimated position fits his $\log$ of July 10 and that of the following day. On Saturday, July 11, Mackenzie embarked at 3 h. 45 a.m. and noted that the river took "a serpentine course" (p. 55), as it actually does north of $68^{\circ} 20^{\prime} \mathrm{N}$. (Fig. 4). He now stopped logging courses and distances, but described recognizable landmarks. "About seven we saw a ridge of high land" (p. 55). This refers to the Caribou Hills. Franklin "first gained a view of the range of hills that Mackenzie drew on the Eastern side of the river" half an hour after leaving $68^{\circ} 15^{\prime} 50^{\prime \prime} \mathrm{N}$. on August 13, 1825 (Franklin 1825a, p. 226; 1828, p. 30). Mackenzie would certainly have seen them 3 hours after departing from a camp at $68^{\circ} 20^{\prime} \mathrm{N}$.

At 12 Mackenzie landed. "From this place [where he had landed at noon] for about five miles, the river widens, it then flows in a variety of narrow, meandering channels, amongst low islands, enlivened with no trees, but a few dwarf willows" (Mackenzie 1801, p. 56). On the map (Fig. 5) of this region is shown a definite widening point in the Middle Channel at about $68^{\circ} 54^{\prime} \mathrm{N}$. Going 50 miles up river from this point, a distance roughly equal to the previous day's rate of travel for 8 hours, brings one close to $68^{\circ} 20^{\prime} \mathrm{N}$., confirming both positions.

The maps show three exits from the Middle Channel at the 69th parallel. Mackenzie did not go northeast towards Tununuk. He went either westerly along the channel south of Langley Island, or northwesterly through the maze of islands bounded by Ellice and Langley islands on the west and Richards Island on the east (Fig. 5). If he had taken the southwest branch, then, according to a modern map and to Franklin's diary and published narrative, Mackenzie would not have found himself "in a variety of narrow, meandering channels". Neither would he proceed, as he did on the following day, July 12, "on the same meandering course", nor would he have been "at a loss what course to steer" (pp. 58-59).

The waterway leading west is broad and definite on a modern map, on the 1825 chart made by Navy surveyor R. N. Kendall who accompanied Franklin, and on Franklin's 1828 map. On August 14, 1825 Franklin's party moved easily and quickly from just south of $68^{\circ} 40^{\prime} \mathrm{N}$. to an evening camp 
on Pitt Island (Franklin 1828, pp. 31-32). Setting out from nearly the same part of the river, Mackenzie spent practically 2 whole days reaching the outer edge of the delta; during part of each day he was in a meandering maze of channels. The two expeditions did not tread the same path. Furthermore, the southwest exit would have brought Mackenzie either to Shallow Bay or to Ellice Island, which are both south of $69^{\circ} 01^{\prime} \mathrm{N}$., $69^{\circ} 07^{\prime} \mathrm{N}$., and $69^{\circ} 14^{\prime} \mathrm{N}$., his most northerly latitudes. In a moment it will be argued that these latitudes are really south of his actual positions; therefore he could not have arrived at Shallow Bay or Ellice Island.

Franklin thought that Mackenzie had gone north from the Middle Channel. "At length the main stream took a turn to the S.S.W., which we followed, though there was a branch going northwards, but it seemed to be much impeded by mud banks*." Franklin's footnote to this sentence reads: "An attentive perusal of Sir Alexander Mackenzie's narrative leads me to the conclusion, that it was this northern branch which that traveller pursued in his voyage to Whale Island" (Franklin 1828, p. 31). His opinion carries even more weight when one considers that he revised a first impression that Mackenzie had followed the south-southwest branch. Finally, Mackenzie himself said that he went north. When he camped for the night of July 11-12, he figured the course for the day's travel "at about NW" (Mackenzie 1801, p. 57). So, after midday on July 11 he headed out of the Middle Channel on a compass direction that represented nearly true north and camped at 8 p.m. He spent thus at least 6 hours in travelling.

He does not say when he started the next day, but around 4 a.m. was the usual embarkation time. He travelled until 10 a.m. before coming "to the entrance of the lake" (p. 59), which means another 6 hours. At this point he resumed logging distances and directions. He went westerly (northwesterly true) for 8 miles in approximately 2 hours to the edge of the delta, where he observed $69^{\circ} 01^{\prime} \mathrm{N}$, and westerly (northwesterly true) again for 15 miles in barely 5 hours to "Whale Island", where he obtained the next day a latitude of $69^{\circ} 14^{\prime} \mathrm{N}$. at the northwesternmost point of the island. $\mathrm{He}$ had thus travelled another 7 hours since 10 a.m. and had spent in all 19 hours of paddling since crossing the 69th parallel. How far had Mackenzie gone in a northwesterly compass direction (northerly true) and a westerly compass (northwesterly true) direction during this time? Although he stopped twice to examine abandoned Eskimo camps and once to take the sun's elevation, he must have been far north of $69^{\circ} 01^{\prime} \mathrm{N}$. and also of $69^{\circ} 14^{\prime} \mathrm{N}$.

This conclusion is inescapable. Mackenzie was almost at the 69th parallel by noon on July 11 and left the Middle Channel sometime after midday. There is not a shred of evidence to indicate westerly travel. His stops between the Middle Channel and Mackenzie Bay would not be long ones since he was in a hurry to reach the sea. The Indians were restive and he had promised to turn back soon. The large error in $69^{\circ} 01^{\prime} \mathrm{N}$. is plain and it follows that the error in $69^{\circ} 14^{\prime} \mathrm{N}$. must be as big. How could Mackenzie spend 14 hours in travelling northerly or northwesterly from about $69^{\circ} 00^{\prime} \mathrm{N}$. to $69^{\circ} 01^{\prime} \mathrm{N}$. and only 5 hours going from $69^{\circ} 01^{\prime} \mathrm{N}$. to $69^{\circ} 14^{\prime} \mathrm{N}$.? Fifteen miles 


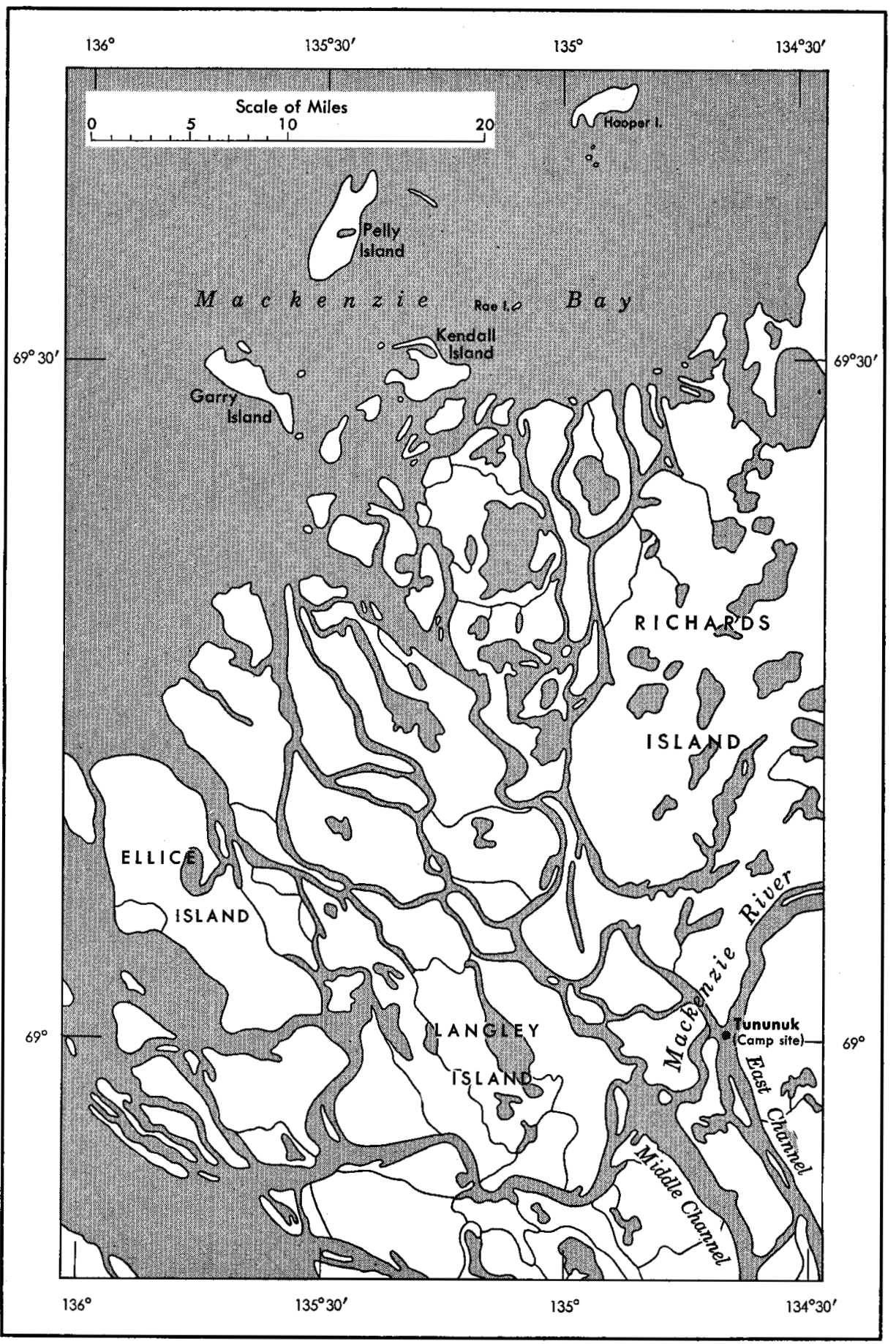

Fig. 5. Redrawn detail of National Topographic Series Sheet Port Brabant, 107 S.W. and 107 S.E. 1:506,880 (actual size). 
through 13 minutes of latitude in 5 hours does make sense. Therefore, his recorded latitudes must be considerably south of his actual positions.

Where was he when the tents were pitched on "Whale Island" at 5 p.m. on July 12, 1789? Many details, too many to be explained by sheer coincidence, point to Garry Island. He had paddled 23 miles, 15 of these across open shallow water, in a "westerly" direction to "Whale Island" after reaching "the entrance to the lake". The westerly compass direction corrects to a northwesterly true direction. If the true direction of travel were retraced, 15 miles of travel in a southeasterly direction from the northwestern point of Garry Island would bring us to the outer edge of the delta and the mouth of an 8-mile-long outlet to Mackenzie Bay. Such an opening exists in that direction from Garry Island.

Mackenzie made for "the Westernmost point of an high island" (Maczenkie 1801, p. 60). Garry Island's high hill is near its western end. If the maximum southerly error of Mackenzie's latitude-finding is added to $69^{\circ} 14^{\prime} \mathrm{N}$., then his northernmost position falls near $69^{\circ} 30^{\prime} \mathrm{N}$., the latitude of Garry Island's westernmost point. "Whale Island" was described as running east-west by compass, northwest-southeast true. This is the trend of Garry Island.

Soon after landing on "Whale Island", Mackenzie "proceeded... to the highest part of the island, from which we discovered the solid ice, extending from the South-West by compass to the Eastward. As far as the eye could reach to the South-Westward, we could dimly perceive a chain of mountains, stretching further to the North than the edge of the ice, at the distance of upwards of twenty leagues. To the Eastward we saw many islands" (p. 60). There are many islands to the east and south of east from Garry Island.

The same mountains were seen by Franklin from Garry Island on August 16, 1825. "We hastened to the most elevated part of the Island, about two hundred and fifty feet high, to look around; and never was a prospect more gratifying than that which lay open to us. The Rocky Mountains were seen from S.W. to W. $1 / 2 \mathrm{~N}$., and from the latter point, round by the north, the sea appeared in all its majesty, entirely free from ice, and without visible obstruction to its navigation" (Franklin 1828, pp. 35-6).

The similarity of these descriptions - and another is yet to comemay not be accidental. Time and direction of travel, and a corrected latitude combine to place Mackenzie at least close to Garry Island. It is the only island northwest of the delta and near Mackenzie's probable position that has a hill high enough from which to see the mountains to the south and west. Neither Franklin, Mackenzie, nor other visitors to this region described any other high hills except the northeast tip of Kendall Island. For the moment, the most conservative inference is that the hills of Garry Island and "Whale Island" could be the same.

Besides inaccurate latitudes, which can be corrected, only two major details of Mackenzie's description of "Whale Island" do not fit Garry Island: its dimensions, and "two small islands in the ice, to the North-West by 
compass" (Mackenzie 1801, p. 63) seen on July 13. The islands: a modern map shows only Pelly Island bearing northeast from Garry Island. However, Franklin saw and mapped two islands bearing northeast, the "Pelly Isles". Mackenzie's "two small islands" were true north from "Whale Island". They could be northeast, for his log of directions shows two similar gross errors; once in Great Slave Lake and once on the river, directions differed from true by a full quarter of the compass. "Whale Island's" dimensions of 7 leagues by half a mile can be reconciled with those of Garry Island without straining the evidence. Mackenzie in the whole of his first journey uses the word league less than half a dozen times, and mostly to describe objects seen at a distance; it is a very rare variation from the plain miles used to indicate distances travelled or the sizes of islands. Seven leagues instead of 7 miles may be a simple lapse of memory or faulty copying from a log book. If half a mile was a misreading of 1 to 2 miles, then Garry Island is not inaccurately described as being 7 by 1 to 2 miles. This supposition is, for two reasons, not far-fetched.

First, the Stowe MS. 793 in the British Museum, on which the published journal of 1801 is based, is not Mackenzie's original logbook. In a letter dated Mar. 5, 1794, from Fort Chipewayan, Mackenzie wrote his cousin Roderick that he had begun copying "my Journal", a task he admitted to be irksome. "I took such a habit of thinking so long on a subject that I sometimes walked backward and forward musing, for hours, at the end of which I could not tell what it was about... It is a work, I find, that requires much more time than I was aware of." (Wade 1927, pp. 232-3.) Although an anonymous pencilled entry on the first flyleaf folio 1 of the Stowe MS. 793 states that the manuscript is in Mackenzie's handwriting, it is not exactly like the handwriting of letters signed by Mackenzie. There is thus room for doubting the correctness of the description of "Whale Island"; errors could have crept in through copying between 1794 and 1801.

Second, the description of the island and the drawing of it do not agree, a discrepancy that has gone unnoticed. Mackenzie drew "Whale Island" as being about 8 miles long and 2 to 3 miles wide and showed it as extending east-west near $69^{\circ} 14^{\prime} \mathrm{N}$. (Fig. 1). Its shape and general position in relation to the delta and its offshore islands are similar to the position of Garry Island. The scale drawing of it is just as valid as the doubtful description and, joined to all the other evidence, is proof that "Whale Island" and Garry Island are the same.

"Whale Island" owed its existence to Mackenzie's journey and narrative; but its appearance on maps up to 1939-45 originated with his description and Franklin's mapping of it "According to Sir Alexander Mackenzie". A most curious fact is that Franklin never mentioned seeing the island in the position in which he charted it in 1828. On August 15, 1825 his party landed near a hummock on Ellice Island. "The haze cleared off ... when we were at the top of this hummock... we got an indistinct view of land bearing from South to WSW compass, which we supposed to be part of the Whale Island of Mackenzie (Fig. 6). It had hitherto been hidden from 
our view by the fog" (Franklin $1825 \mathrm{a}$, p. 230 ). His position, $69^{\circ} 03^{\prime} 45^{\prime \prime} \mathrm{N}$. $135^{\circ} 47^{\prime} 32^{\prime \prime} \mathrm{W}$., is very close to the present shore of Ellice Island. On the 16 th "we pursued our course along the Eastern shore, as far as the next hummock where the Lat ${ }^{\text {de }} 69^{\circ} 7^{\prime} 14^{\prime \prime}$ No and variation $48^{\circ} 43^{\prime}$ East were obtained, and at another opportunity the Longitude $135^{\circ} 49^{\prime} 26^{\prime \prime}$ West. From the top of this hummock we had a more distinct view of Whale Island" (p. 232). Kendall's map shows "Part of Whale Island" south and west of Ellice Island.

The only islands shown on that map, and mentioned in Franklin's diary as having been seen southeast of Garry Island were the Kendall Isles. "... on landing just as the sun was setting we hastened to the highest part of the island to gain the view at this best time for discovering distant objects... There were two groups of Islands visible, one bearing $\mathbf{E}$ by $\mathbf{S}$, which I named after my friend and companion Kendall, the other NE, to which the name Pelly was given... The Island on which we were, I had the happiness of calling after my much esteemed friend $\mathrm{Mr}$ Garry the Deputy Governor of H B Co." (Franklin 1825a, pp. 233-4).

In a letter dated September 6, 1825, to the Under Secretary of State, Colonial Department, Franklin summed up the results of his reconnoitering dash to the Arctic. "We came to the salt water, about 20 miles beyond the point at which Sir A. Mackenzie stopped... The main shore Eastward of the River which is low, and trends in a true SE direction is not visible from Garry's Island, but there are many Islands in the same direction which fringe the coast." (Franklin 1825b).

In his book Franklin did not mention seeing "Whale Island". The island that he had supposed to be "part of Whale Island" and had been thus charted by Kendall in 1825 was given the name of Pitt. In 1828 "Whale Island" was put southeast of the Kendall Isles, where there were "many islands in the same direction which fringe the coast". The "many islands", presumably of the delta, however, were not shown. Obviously Franklin had changed his mind about the proper location of "Whale Island". He concluded that Mackenzie must have taken a northern rather than a western exit from the Middle Channel at the 69th parallel. He had to accept Mackenzie's latitudes as correct since he had no means of checking them and apparently did not notice, or ignored, the discrepancy between Mackenzie's map of "Whale Island" and its description. He supposed that the islands that Mackenzie saw to the northwest were the Kendall Isles, although he knew Mackenzie's direction to be compass.. He qualified this part of his map by placing the phrase "According to Sir Alexander Mackenzie" by "Whale Island". There it remained on the maps until aerial photography revealed this area to be delta country.

The disappearance of "Whale Island" has been argued to be the inevitable consequence of an expanding delta. There are several strong reasons for discarding the theory that the island was assimilated into the delta as a result of massive sedimentary deposition. First, Mackenzie paddled from the 69th parallel for some 14 hours northwards through the delta to 
its seaward edge and then for 5 more hours to "Whale Island". Franklin, although he did not attempt to chart them, said in a long-buried letter that there were "many islands" southeast of Garry Island (Franklin 1825b). Evidently the delta had not changed appreciably between 1789 and 1825 , nor has it since. Second, in 1849 and 1850 two officers of the Royal Navy, W. H. Hooper and W. J. S. Pullen, were engaged searching for Sir John Franklin, who was then lost in the Arctic. A clause in Pullen's instructions required him to visit, if possible, "Whale Island" (Hooper 1853, p. 267). He tried: "On the evening of the 27th [Sept. 1849] we entered the River... We did not go far up for Whale Island is yet to be visited . . . On the morning of the 28th I ... ran across Shoal water bay and along the north shores of Tent Island and steered to N.E. and in the evening got up to Ellice Island when we were stopped by strong N.W. winds" (Pullen 1848, p. 21). On the 29th Pullen found the wind still strong from the same direction and made up his mind to return.

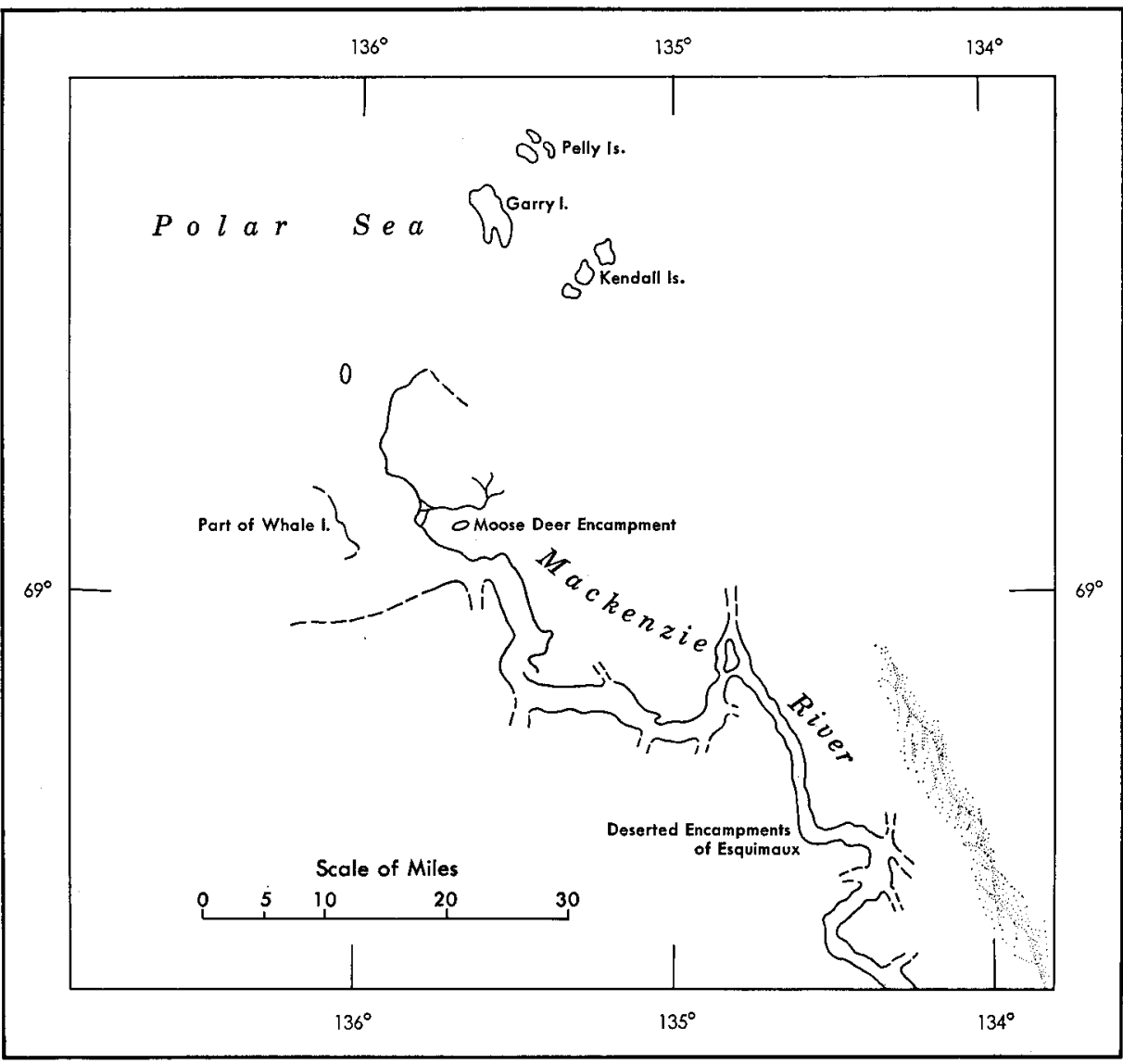

Fig. 6. Redrawn detail of map "Routes of the Land Arctic Expedition... Captain Franklin, R.N., from Great Bear Lake River to the Polar Sea...1825" (actual size). 


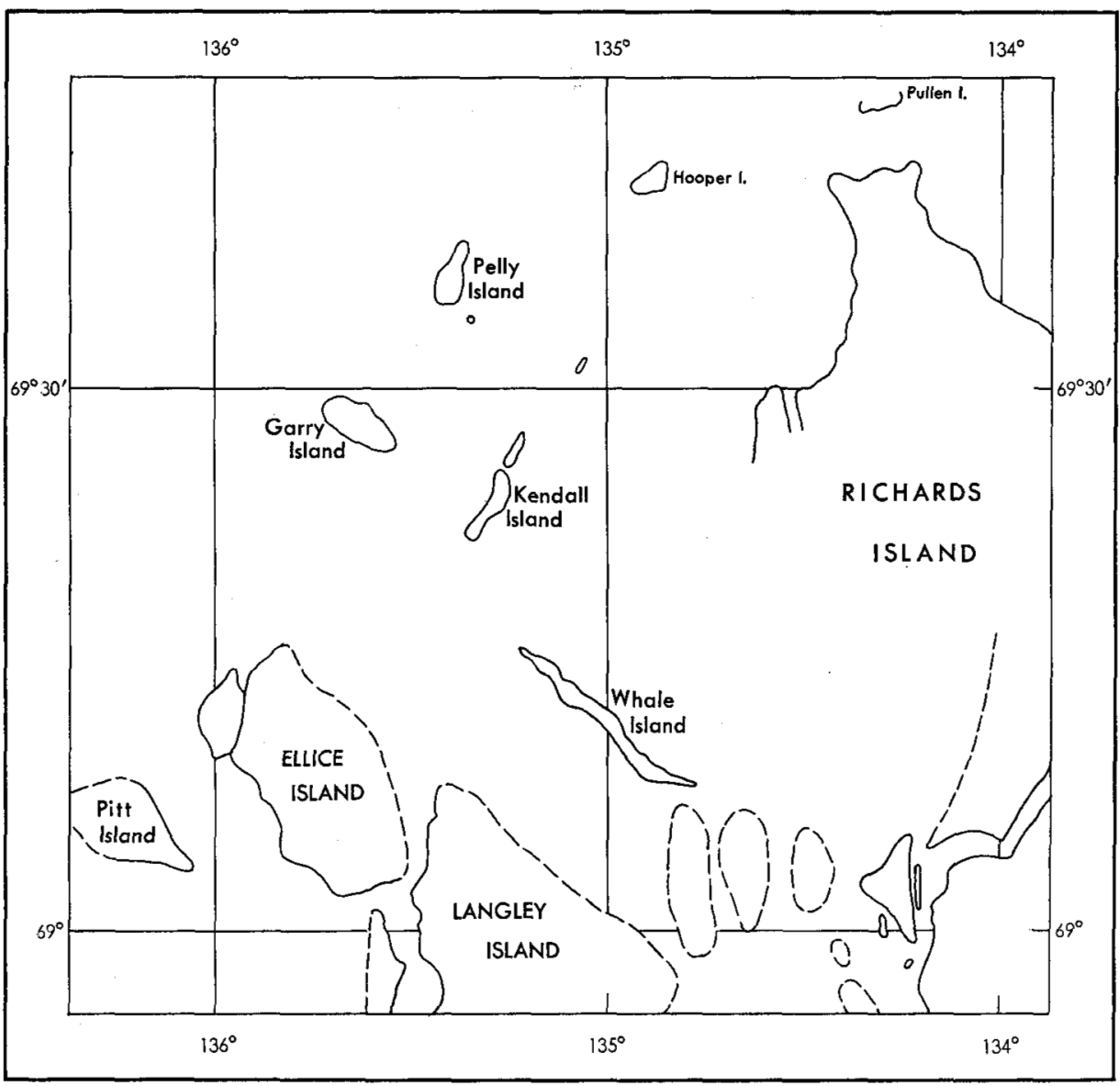

Fig. 7. Redrawn detail of map "Part of the Arctic Coast of North America between the River McKenzie and Cape Bathurst shewing the tracks of the boats under the command of W. J. S. Pullen Commander R. N. from the 22nd July to the 3rd of August 1859" (actual size).

The two men wintered at interior Hudson's Bay Company posts. On July 20, 1850, renewing their arctic search, they entered the Mackenzie Delta and on July 22 "landed on Garry Island to dine, and had a fine view from its highest part" (Hooper 1853, p. 341). Pullen wrote: "While dinner was preparing I walked to the highest part of the Island . . . and got a good view around. To seaward an unbroken line of ice (or from $N 78^{\circ} \mathrm{W}$ to $\mathrm{N} 30^{\circ} \mathrm{E}$ ) was visible, with a strong blink to the S.W. To the N.E. was clear open water and toward the Pelly Isle, which after our meal we made for, under oars ... and at half past eight we landed on its Northern shore and pitched the camp" (Pullen 1850, pp. 7-8). It is remarkable how similar are Franklin's and Pullen's views from Garry Island to Mackenzie's from "Whale Island". On July 23 Hooper and Pullen camped on Kendall Island, but did not report seeing "Whale Island" and its high hill, although according to Franklin's 
chart they were within a few miles of it. However, Pullen did view the surroundings from "the N.E. point of the Island which was high... from South around to $\mathrm{N} 62^{\circ} \mathrm{E}$ was also land, which I take to be the western shores of Richardsons Island" (Pullen 1850, p. 9) (Fig. 7). Pullen saw delta country where Franklin had mapped "Whale Island" a quarter of a century before. His directions are compass rather than true and, if $40^{\circ}$, allowing for easterly variation, be added to South and to $\mathrm{N} 62^{\circ} \mathrm{E}$ bearings, then bearings of $102^{\circ}$ and $220^{\circ}$ true from the northwest tip of Kendall Island enclose delta land. These corrected bearings not only fit Pullen's chart, but they also correspond rather closely to the bearings of the northern and western edges of the delta from the present northeastern tip of Kendall Island.

On July 24 the officers travelled east to Richards Island between $69^{\circ} 25^{\prime} \mathrm{N}$. and $69^{\circ} 30^{\prime} \mathrm{N}$. according to Pullen's track chart. "Working across from Kendall Island, on standing to the Southward we found the water very shoal, and when we saw the land in the same direction it appeared low, sweeping around in a deep bight, and connecting with Kendall Island. From Kendall Island there appeared to me a connection; or at all events only a separation of low swampy land by narrow channels; and as we saw deer on the latter, one of which our hunters shot, the remainder of the herd wading off to a low patch I think is enough for saying that they are connected; for a swim from Kendall Island to the Main without some resting place would be a long one." (Pullen 1850, p. 9). Enough has been said to refute the theory that a growing delta engulfed "Whale Island". Pullen's description fits the kind of country that Mackenzie said he travelled and that Franklin saw but did not map.

Returning later from their eastward arctic search, the two men reached Mackenzie Bay during the last week in August where they discovered and named Hooper and Pullen islands. On August 26 they camped on Garry Island. "Next day we steered to the southward and sought for a channel... to ascend the Mackenzie, failing in which we proceeded to the westward, and after more than one disappointment and difficulty, finally entered the river on the 31st, by the channel we had discovered last year" (Hooper 1853, p. 365). Pullen's diary confirms in detail Hooper's summary sentence and shows that their boats skirted the western edge of the delta and found it much as it exists today. Certainly they should have been once more in sight of the high hill of the Franklin-mapped "Whale Island". Of course they did not see it. Yet an Admiralty chart, published in 1856 and incorporating some of their discoveries, still left "Whale Island", 20 miles long, half a mile or more broad, stretching between latitudes $69^{\circ} 14^{\prime} \mathrm{N}$. and $69^{\circ} 07^{\prime} \mathrm{N}$. where Franklin had placed it in 1828 instead of the "many islands ... which fringe the coast".

Because Pullen's discovery of the shape of the delta (long before its outline was revealed by aerial photography) was not charted, because Mackenzie's errors in latitude and his drawing of "Whale Island" have gone unnoticed, and because Franklin mapped "According to Sir Alexander 
Mackenzie" an island he did not see, "Whale Island" is now presumed missing and its name rescinded.

The author is indebted to the Scott Polar Research Institute for kind permission to quote from the Franklin MS. 248/280/1 in their possession. The quotations from unpublished crown-copyright material in the Public Record Office, London, have been reproduced by permission of the Controller of H.M. Stationary Office.

\section{References}

Franklin, J. 1825a. MS. 248/280/1. Scott Polar Research Institute. Vol. 1, pp. 214-53 (microfilm). 1825b. Letter to Under Secretary of State, Colonial Dept., 6 Sept. 1825. Public Record Office 259 C. O. 6/17. London (microfilm).

1828. Narrative of a second expedition to the shores of the Polar Sea in the years 1825, 1826 and 1827. London: John Murray, 320 pp.

Hooper, W. H. 1853. Ten months among the Tuski. London: John Murray, $417 \mathrm{pp}$.

Mackenzie, A. 1801. Voyages from Montreal on the River St. Laurence through the continent of North America to the Frozen and Pacific Oceans in the years 1789 and 1793. London: Cadell \& Davies, and others, $412 \mathrm{pp}$.

Pullen, W. J. S. 1849. Public Record Office 753 Adm. 7/189. London. p. 21 (microfilm). film).

1850. Public Record Office 753 Adm. 7/191. London. pp. 7-43 (micro-

Wade, M. S. 1927. Mackenzie of Canada. London: Blackwood, 332 pp. 